\title{
УДК 821.161.2:81'42'06
}

ЮЛІЯ ГРИШКО

(Полтава)

orcid.org/0000-0002-5607-0126

https://doi.org/10.33989/2524-2490.2019.30.188770

\section{ОКАЗІОНАЛЬНІ КОНТАМІНАЦІЇ В СУЧАСНОМУ УКРАЇНСЬКОМУ ПОЕТИЧНОМУ ДИСКУРСІ}

У статті наведені результати лінгвістичного аналізу сучасного украйнського поетичного дискурсу С. Жадана, О. Ірванця, В. Неборака, О. Забужко, А. Аюбки, В. Цибулька, І. Низового та ін. Виокремлено три основні типи оказіональних контамінацій: квазіномінація, дефісація та слешинг. Установлено, щзо найпродуктивнішим авторським інтегративним утворенням є дебісація. Підкреслено, що, крім основних контамінацій, існують також змішані типи.

Ключові слова: сучасний український поетичний дискурс; контамінація; оказіональний; інтегративне утворення; квазіномінація; дефісація; слешинг.

Із другої половини XX століття в арифметичній прогресії зростає кількість наукових філологічних праць, присвячених проблемам оказіоналістики. Уживання інноваційних лінгвістичних одиниць можна спостерігати насамперед у художній комунікації та текстах 3MI, де панує «свято вербальної свободи» (Попова, 2005). Найбільш відкритий і динамічний лексичний рівень мови $є$ таким, що всотує, відповідно, найбільшу кількість авторських новотворів. Звідси - позиції лідерства наукових напрацювань саме в галузі оказіональної лексики.

У русло питань оказіональної лексики й авторського словотворення спрямували свої студії Г. Вокальчук, І. Лощинова, О. Турчак, Ж. Колоїз, Л. Кривко, В. Гладка, И. Кравчук, Ю. Калужинська, Н. Бабенко, В. Ізотов, Т. Попова, М. Пахомова, Р. Намітокова, Е. Ханпіра, П. Ніссіле, В. Церула та ін.

Мовні оказіональні засоби проміжних типів, як-от фонетико-яексичні, залишаються ще не дослідженими. Лінгвісти дише вказують на існування таких одиниць, як фонетико-лексичні оказіоналізми, що є водночас і складними звуковими комплексами, які мають у своїй структурі повнозначні лексеми (Попова, 2005).

Мета статті - виокремити інтегративні контамінації в сучасному українському поетичному дискурсі, що передбачає реалізацію таких завдань: 1) описати контамінаційні утворення в доробку українських авторів; 2) класифікувати складні оказіоналізми залежно від способу їхнього функціювання в контексті.

Матеріалом дослідження стала віршована творчість С. Жадана, О. Ірванця, В. Неборака, О. Забужко, О. Гусейнової, Д. Лазуткіна, А. Любки, А. Якимчук, Г. Пустовгар, Ze Ja, I. Низового, В. Цибулька, В. Терена I. Римарука, Кузьми Скрябіна (А. Кузьменка), В. Голобородька, В. Кордуна. Методом суцільної вибірки були виписані й підраховані контамінаційні оказіональні утворення.

Типологія оказіональних одиниць у славістиці є досить розгалуженою. Н. Бабенко виокремлюе п'ять типів оказіоналізмів (Бабенко, 1997): фонетичні, лексичні, граматичні, семантичні, оказіональні поєднання слів. В. Ізотов доповнює цю класифікацію графодериватами (Изотов, 1998). Г. Вокальчук додає квазіномінації та неозапозичення (Вокальчук, 2006). О. Ликов утверджує юкстапозити (Лыков, 1976). Е. Ханпіра виділяе також фразеологічні та синтаксичні оказіоналізми (Ханпира, 1972). Р. Намітокова пропонує типологію нових слів, складниками якої є неологізми та новотвори (авторські художні й наукові; неавторські - розмовні, дитячі) (Намитокова, 1986).

Комплексні оказіональні фонетико-лексичні новотвори називатимемо контамінаціями - інтегративними сполуками, які внаслідок здиття компонентів перетворилися на суцільно оригінальну дінгвістичну одиницю.

Контамінації належать до оказіоналізмів третього ступеня, тобто вони є абсолютно нестандартними утвореннями із суттєвими відхиленнями від дериваційної норми. Інтегральні оказіональні інновації в українському поетичному дискурсі почасти змодельовані за зразком полісинтетичних мов, чим наближаються до глосолалії - мовленнєвого потоку з порушенням усталених нормативів, що притаманне ворожінням, замовлянням, магічним ритуальним дійствам (Гром’як, Ковалів, \& Теремко, 2006). Це свідчить про те, що використання складних оказіональних сполук підпорядковане мистецькій прагматичній меті стійкого емоційного впливу на адресата. Чим оригінальнішою є контамінація, тим інтенсивніше виявляє себе рівень експресії, яка здатна переходити в сугестію. Розвиток контамінованого оказіонального словотворення сприяє зростанню аглютинативних рис у семантиці й структурі похідного слова, що є найзагальнішою тенденцією сучасної словотвірної системи (Никитина, 1972).

Під час лінгвістичного аналізу українського поетичного дискурсу були відібрані факти використання митцями оказіональних контамінацій. Серед них виділяємо три основні типи інтегративних сполук:

1. Дефісації (63\%) - складні сполуки, семантична єдність яких графічно позначена неузусним уживанням дефісів (від двох-трьох і більше). Найпродуктивніше такі контамінації функціюють у поетичній мові О. Забужко, адже письменниця часто використовує декілька оказіональних сполучень у межах одного твору. Наприклад, у поезії «Із циклу “Нічні метелики” » дефісації використано у двох рядках поспіль:

<...> A потім, як в шаниі, залеглі в роботу-й-сім'ю,

Підем проживати уривки Не-Наших-Історій <...> (Забужко, 2009).

А вірш «Тридцята зима» характеризується наявністю двох дефісацій в одному рядку:

(c) Гришко Ю. 
$<\ldots>$ В ту зиму в мене не було, крім книг,

нічого. Втім, не рятували й книги

од світу-без-людей і од землі-без-снігу <...> (Забужко, 2009).

У поетичному дискурсі О. Забужко дефісація сприяє зміцненню семантичних зв'язків між лексемами, які є складниками авторських інтегративних утворень. Мисткиня надає поняттям авторської семантизації.

І. Низовий послуговується дефісаціями для створення іронічного ефекту, як, наприклад, у віршах «Артистка Леся Репетуха-Баб-ель-Мандебська» та «Нi, не Баба-Яга...»:

$<\ldots>$ Hi-не-Баба-Я̈а

Від рогозу полола лозу <...> (Низовий, 2018).

Також поети вводять у текст дефіси для поглиблення символізації безкінечності, яка є можливою для декодифікації винятково в контексті. Наприклад, у вірші А. Якимчук «тримаю їі на відстані...»це безкінечність листів про кохання:

<...> чому мені пишеш твій-я-твій-я

чому? <...> (Якимчук, 2018).

А в поезї̈ В. Кордуна «Після півночі»- неперервний шум:

$<\ldots>$ жумить-i-uуммить-i-uуммить

верба в узголів' $i$

при старому шляху

при юній тривозі <...> (Кордун, 2005).

У віршованій комунікації Г. Пустовгар дефісація відтворюе філософську неосяжність концепту МІСТО: Місто-загадка-вигадка-загадка,

Де ночують тумани і протяги <...> (Пустовгар, 2007).

В. Цибулько у вірші «Янголи і вовки» відтворюе складну психологічну глибину стосунків між жінкою та чоловіком, не виключаючи й іронічне враження, підсилюване, крім дефісації, власне фонетичним оказіоналізмом та заголовком твору:

<..> пунктом а) проголошено прямо

полюблю-погублю а загальна концепція

то свята послідовність

полюблю-погублю-погублю-погублю-погублю-погублю

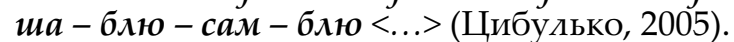

2. Квазіномінації (31\%) - сформовані злиттям синтаксичної конструкції шляхом умисного уникнення пробілів між словами. Вони 3-поміж усіх контамінацій найдужче тяжіють до глосолалій, як-от у творах О. Ірванця «Прощальний романс», І. Римарука «Глосолалія», В. Голобородька «Літо літописуе» та ін.:

Це ж, може, остання любов,

Тожнекидайіï! (Ірванець, 2010);

Лimo лimonuсуе про луу -

ярощу бджіл.

Лimo лimonисуе про поле -

проріщуу пшениці <...> (Голобородько, 2005);

<...> даремна хода тверда не тут

освітить межу заповітну

словозвізда

істинновамкажу <.. > (Римарук, 2008).

Справжньою «вершиною контамінації» є вірш-квазіномінація А. Дюбки «Тасю», де не використано жодного пробілу, чим досягнуто максимального сугестивного впливу:

<...> немаєбарокосуцільнаеклектика

немаепоетіводніпияки

минаєосіньлишаютьсясектита

деякізанджібодайбивони (Дюбка, 2018).

Кузьма Скрябін (А. Кузьменко) у вірші «Порш пана мера» моделює мовну гру, адже, на відміну від заголовка твору, де всі слова написані окремо, у тексті використана квазіномінація Пори Панамера з використанням великих літер, що при первинному аудіальному (та навіть і візуальному) сприйнятті адресатом декодифікуеться як нова модель автомоб̆іля марки «Porsche» (деякий «Porsch' Panamera»):

<..> Порш Панамера! Нулячий Порш Панамера!

Я плачу, Пори Панамера! <...> (Кузьма Скрябін, 2015).

Поширеними в українському поетичному дискурсі є комбінування графіксатів із квазіномінаціями та дефісаціями. Зокрема, у вірші В. Цибулька «Через літа Вода Уліяна ІІ» спостерігаємо квазіномінацію в поєднанні з виділенням великим шрифтом:

$<\ldots>$ він ЯК Бог ДУХСИНОТЕЦЬ

триєдиний носій мого я<... (Цибулько, 2005).

Інтернет-автор Zе Ја експериментує через зрощення великого шрифту й дефісації:

Галькою всетелний шлях, пересічений кроками - КУДИСь-ІЗВІДКИСЬ -

Toro,

Кому не боляче ходити по гострих каміниях <...> (Ze Ja, 2016);

<... Все-таки перегляну КАВИ-НЕ-ВЖИВАННЯ - 


\section{I додаватиму трохи}

Сонияя в напій <...> (Ze Ja, 2016).

I. Низовому вдалося поєднати дефісацію й квазіномінацію в одному творі. При цьому автор посилює емоційний вплив на реципієнта використанням алітерацій передньоязикового дзвінкого свистячого [3]: 3-нічого-з-нічого-а-знічев'я

запалюcь i зопалу спалю

о самозвеличенонікчемна <... (Низовий, 2016).

3. Слешинги (6\%) - від англ. slash - новотвори з використанням скісної риски. Слешинг, який виконуе роль дефіса в складі юкстапозиції, виявлено лише в поетичному доробку С. Жадана:

мама/кока з тобою листя цибулі

мокрі волокна бавовни овочів і морів <...>

мама/кока якщо ти дихаєщ зябрами ти ковтаєш

воду ніби вино і чорний хліб немов наживку <...>

воском лежать небеса воском і шоколадом

любов мама/кока дорожча аніж виправдання <...> (Жадан, 2011).

У сучасному українському поетичному дискурсі складні оказіональні номінації - контамінації є продуктивним засобом впливу на адресата в процесі художньої комунікації. Виділено три основні типи оказіональних інтегративних сполук: дефісації, квазіномінації та слешинги. Серед додаткових типів можна виокремити змішані: дефісація+квазіномінація, графіксація+квазіномінація, графіксація+дефісація тощо. Найпродуктивнішим типом фонетико-лексичних контамінаційних утворень $є$ дефісація, що становить 63\% від загальної кількості оказіональних контамінацій.

Наші подальші дослідження спрямовані на поглиблене вивчення стилістичних можливостей українського поетичного дискурсу, зокрема передбачене опрацювання прозового доробку сучасних митців.

\section{СПИСОК ВИКОРИСТАНИХ ДЖЕРЕЛ}

Бабенко Н. Г. Окказиональное в художественном тексте. Структурно-семантический анализ : учеб. пособ. URL: http://elibrary.It/resursai/Uzsienio\%20leidiniai/Kaliningrad/Uchebnye-e-pub/slavistika/KGU_sfz_06.pdf (дата обращения: 26.10.2017).

Вокальчук Г. М. Я - беззразковості поет (словотворчість М. Семенка) : монографія. Рівне : Перспектива, 2006. 201 с. Голобородько В. І. Летюче віконце : вибрані поезї / вст. ст. І. М. Дзюби. Київ : Укр. письменник, 2005. 463 с. Гусейнова О. Супергерої : поезії. Аьвів : Вид-во Старого Лева, 2016. 191 с.

Жадан С. В. Лілі Марлен : книга нових та вибраних віршів. Харків : Фоліо, 2011. 186 с.

Забужко О. Аруга спроба : вибране. 2-ге вид., виправл. і доп. Київ : Факт, 2009. 432 с.

Ірванець О. Мій хрест : поезії. Харків : Фоліо, 2010. 122 с.

Изотов В. П. Параметры описания системы способов русского словообразования. Орёл : ОГУ, 1998. 149 с.

Кордун В. Трава над травою : поезії. Київ : Неопалима купина, 2005. 176 с.

Лазуткін Д. Поезії. URL: http://dotyk.in.ua/lazutkin.html (дата звернення: 23.02.2018).

Літературознавчий словник-довідник / за ред. Р. Т. Гром'яка, Ю. І. Коваліва, В. І. Теремка. Київ : Академія, 2006.752 с.

Аыков О. Г. Современная русская лексикология (русское окказиональное слово). Москва, 1976. 120 с.

Пюбка А. Поезіiі. URL: https://onlyart.org.ua (дата звернення: 12.03.2018).

Намитокова Р. Ю. Авторские неологизмы: словообразовательный аспект. Ростов-на-Дону : РГУ, 1986. 156 с.

Неборак В. Поезії. «Бу-Ба-Бу» (Юрій Андрухович, Олександр Ірванецьь, Віктор Неборак): вибрані твори: поезія, проза, есеїстика / авт. проект, упор. бібліогр. відом. та прим. В. Габера. Львів, 2008. С. 304-348.

Низовий I. Поезії. URL: http://maysterni.com (дата звернення: 06.03.2018).

Никитина $\Lambda$. К. Окказиональные слова и способы их образования (на материале современной поэтической речи). Актуальные проблемы русского словообразования : сб. статей. Самарканд, 1972. Ч. 1. С. 190-193.

Попова T. В. Русская неология и неография : учеб. эл. текст. пособ. URL: https://studfiles.net (дата обращения: 07.09.2018). Пустовгар Г. Поезії. Поети полтавської «Просвіти» : антологія / упор. М. Дяченко. Полтава : РІК, 2007. С. 101-118. Римарук І. Сльоза Богородиці : вибране. Київ : Дніпро, 2008. 400 с.

Скрябін Кузьма. Я, Шонік і Шпіцберген. Харків : Фоліо, 2015. 122 с.

Терен В. Жити : триптих : вірші. Київ : Дніпро, 2016. 208 с.

Ханпира Э. Окказиональные элементы в современной речи. Стилистические исследования : сб. науч. ст. Москва, 1972. C. 245-317.

Цибулько В. М. Ангели і тексти : поезії. Харків : Фоліо, 2005. 223 с.

Якимчук А. Поезіï. URL: http://dotyk.in.ua/yakymchuk.html (дата звернення: 06.03.2018).

Zе Ја. Поезї. 100 молодих поетів Украӥни. Київ : Автограф, 2006. С. 32.

\section{REFERENCES}

Babenko, N. G. (1997). Okkazionalnoe v khudozhestvennom tekste. Strukturno-semanticheskii analiz [Occasional in the belletristic text. structural and semantic analysis]. Retrieved from: http://elibrary.It/resursai/Uzsienio\%20leidiniai/Kaliningrad/Uchebnye-e-pub/slavistika/KGU_sf__06.pdf [in Russian].

Holoborodko, V. I. (2005). Letiuche vikontse: Vybrani poezii [The flying window: Selected poems]. Kyiv: Ukr. Pysmennyk [in Ukrainian].

Huseinova, O. (2016). Superheroi: poezii [Superheroes: poems]. Lviv: Vydavnytstvo Staroho Leva [in Ukrainian].

Hromiak, R. T., Kovaliv, Yu. I. \& Teremko, V. I. (Eds.). (2006). Literaturoznavchyi slovnyk-dovidnyk [Literary reference dictionary]. Kyiv: Akademiia [in Ukrainian].

Irvanets, O. (2010). Mii khrest: poesii [My cross: poems]. Kharkiv: Folio [in Ukrainian].

Izotov, V. P. (1998). Parametry opisaniia sistemy sposobov russkogo slovoobrazovaniia [The parameters for describing of system of Russian word-building ways]. Orel: OSU [in Russian].

Kordun, V. (2005). Trava nad travoiu: poesii [The grass over the grass: poems]. Kyiv: Neopalyma kupyna [in Ukrainian].

Lazutkin, D. (2018). Poesii [Poems]. Retrieved from: http://dotyk.in.ua/lazutkin.html [in Ukrainian]. 
Liubka, A. (2018). Poesii [Poems]. Retrieved from: https://onlyart.org.ua [in Ukrainian].

Lykov, O. G. (1976). Sovremennaia russkaia leksikologiia (russkoe okkazionalnoe slovo) [The modern Russian lexicology (Russian nonce word)]. Moscow [in Russian].

Namitokova, R. Iu. (1986). Avtorskie neologizmy: slovoobrazovatelnyi aspekt [Author's neologisms: word-building aspect]. Rostov on Don: RSU [in Russian].

Neborak, V. (2008). Poesii [Poems]. In «Bu-Ba-Bu» (Yurii Andrukhovych, Oleksandr Irvanets, Viktor Neborak): vybrani tvory: poesiia, proza, eseistyka [«Bu-Ba-Bu» (Yurii Andrukhovych, Oleksandr Irvanets, Viktor Neborak): selected works: poetry, prose, essays] (pp. 304-348). Lviv: Piramida [in Ukrainian].

Nikitina, L. K. (1972). Okkazionalnye slova i sposoby ikh obrazovaniia (na materiale sovremennoi poeticheskoi rechi) [Nonce words and ways of their building (on the base of modern poetical speech)]. In Aktualnye problemy russkogo slovoobrazovaniia [Actual problems of Russian word-building] (pp. 190-193). Samarkand: SU [in Russian].

Nyzovyi, I. (2018). Poesii [Poems]. Retrieved from: http://maysterni.com [in Ukrainian].

Popova, T. V. (2005). Russkaia neologiia i neografiia [Russian neology and neography]. Retrieved from: https://studfiles.net [in Russian].

Pustovhar, H. (2007). Poesii [Poems]. In Poety poltavskoi «Prosvity»: antolohiia [Poets of Poltava «Prosvita»: anthology] (pp. 101-118). Poltava: RIK [in Ukrainian].

Rymaruk, I. (2008). Sloza Bohorodytsi: vybrane [The Virgin Mother's tear: Selected works]. Kyiv: Dnipro [in Ukrainian].

Skriabin, Kuzma. (2015). Ya, Shonik i Shpitsberhen [Shonik, Spitsbergen and me]. Kharkiv: Folio [in Ukrainian].

Teren, V. (2016). Zhyty: tryptykh: virshi [To live: triptych: poems]. Kyiv: Dnipro [in Ukrainian].

Tsybulko, V. M. (2005). Anhely i teksty: poesii [Angels and texts: poems]. Kharkiv: Folio [in Ukrainian].

Vokalchuk, H. M. (2006). Ya-bezzrazkovosti poet (slovotvorchist M. Semenka) [I am a poet of non-standard (creative wordbuilding by M. Semenko)]. Rivne: Perspektyva [in Ukrainian].

Yakymchyk, L. (2018). Poesii [Poems]. Retrieved from: http://dotyk.in.ua/yakymchuk.html [in Ukrainian].

Zabuzhko, O. (2009). Druha sproba: Vybrane [The second attempt: Selected works]. Kyiv: Fakt [in Ukrainian].

Ze, Ja. (2016). Poesii [Poems]. In 100 molodykh poetiv Ukrainy [100 young poets of Ukraine] (p. 32). Kyiv: Avtohraf [in Ukrainian].

Zhadan, S. V. (2011). Lili Marlen: Knyha novykh ta vybranykh virshiv [Lily Marlen: The book of new and selected poems]. Kharkiv: Folio [in Ukrainian].

\section{YULIIA HRYSHKO}

\section{OCCASIONAL CONTAMINATIONS IN THE MODERN UKRAINIAN} POETICAL DISCOURSE

The article deals with results of linguistic analysis of modern Ukrainian poetical discourse by S. Zhadan, O. Irvanets, V. Neborak, O. Zabuzhko, O. Huseinova, D. Lazutkin, A. Liubka, L. Yakymchuk, H. Pustovhar, Ze Ja, I. Nyzovyi, V. Tsybulko, V. Teren, I. Rymaruk, Kuzma Skriabin, V. Holoborodko, V. Kordun. The purpose of the research is to distinguish integrative contaminations in the modern Ukrainian poetical discourse that includes the realization of the next aims: 1) to describe the contaminative formations in creation by Ukrainian authors; 2) to classify the complex nonce words depending on the form of their functioning in the context. As the main method for choice of complex occasionalisms the author used a continuous sampling method which makes it possible to classify the integrative contaminations: it is distinguished three main types of occasional contaminations - quasi-nomination, hyphen and slashing. It is determined that the most productive author's integrative word-forming is hyphen (63\%). The second place takes quasi-nomination (31\%) and third - slashing (only $6 \%$ ).

The author describes that except the ground contaminations there are also mixed types, for example: hyphen+quasi-nomination, graficsation+quasi-nomination, graficsation+hyphen.

In the modern Ukrainian poetical discourse the complex occasional nominations - contaminations - are productive means of influence on addressee during the process of artistic communication.

The article is of great help to teaching of high school students: the results can be used on Ukrainian language studies (stylistics, phonetics, lexicology, linguistic analysis of the text) and also on Ukrainian literature studies (individual style and expressive means of modern Ukrainian poets).

Key words: modern Ukrainian poetical discourse; contamination; occasional; integrative forming; quasi-nomination; hyphen, slashing. 